\title{
IFP News Section
}

\section{Psychotherapy and Psychosomatics}

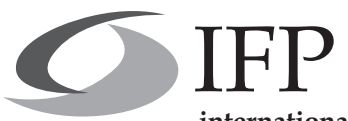

international federation

for psychotherapy
Psychother Psychosom 2008;77:67-68

DOI: $10.1159 / 000111934$

\section{President's Message}

Dear friends and colleagues

This year, I was on sabatical leave for 6 months. Travelling around the world, I had a chance to meet, talk to and learn from many colleagues in Europe, Asia and the USA. In spite of my absence, the Board worked hard, and, as you will see from this message, we were able to get quite some business done.

The Secretarial Office in Zurich is running smoothly under the watchful guidance of Cornelia Erpenbeck. She is responsible for all administrative matters concerning the IFP and may be contacted at her office, should there be any queries. To further optimize the visibility of the IFP, I would like to encourage all our members to introduce a link to the IFP website (http://www.ifp. name) on your respective homepages. We would be happy to do so vice versa: please feel free to approach Cornelia Erpenbeck in case you need a hand!

Presidential Election: According to the bylaws, a new President will have to be elected in 2010. By this time, I will have served as President for 2 full 4 -year terms and will thus not be allowed to stand for election for a third term. Ideally, my successor should be elected in 2008 already so that the President-Elect can serve on the Board for 2 years prior to assuming office, to grant enough time to learn the ins and outs of the organization and the various duties involved. If you have any suggestions as to who should be approached to stand for election, or if you feel you yourself might consider running for President, please contact me directly (u.schnyder@ifp.name) as soon as possible!

New Membership Societies: The Clinical and Counselling Psychology Division of the Chinese Psychological Society was formally accepted as a new membership society. Its President, Dr. Jie Zhong, was notified in written form. A very warm welcome to our first Chinese member! The Swiss Charter for Psychotherapy, a large society serving a total of over 2,000 members under President Dr. Peter Schulthess, also recently joined the IFP. A very warm welcome to our new Swiss member! Three additional societies have submitted their applications for membership.

Congresses: The Chinese-German Congress on Psychotherapy, which was held in Shanghai, China, May 20-23, 2007, to celebrate the 10th anniversary of the German-Chinese Academy for Psychotherapy, was a great success! The congress was hosted by the Shanghai Mental Health Center and supported by the China Association for Psychological Health, Division of Psychotherapy and Counseling, the Chinese Psychological Society, Division for University Students Psychological Counseling, and the Shanghai Doingfeng Hospital. The theme of the conference was 'Changing societies - changing people'.

The planning of the 5th Conference of the Asia Pacific Association of Psychotherapists (APAP) will be organized by IFP member Indonesian Psychiatric Association, Section on Psychotherapy, under the guidance of Prof. D. Bachtiar Lubis in Jakarta, Indonesia, April 5-7, 2008. The congress theme will be 'Listening to the heart of the East'. For further information, see Prof. D. Bachtiar Lubis' welcome letter further down.

Finally, it is my pleasure to announce that we decided to hold the 20th IFP World Congress of Psychotherapy in Lucerne, Switzerland, June 16-19, 2010. The congress will be organized by the Swiss Society for Psychiatry and Psychotherapy (SGPP) (http:// www.psychiatrie.ch), in collaboration with a number of other professional organizations which will be announced at a later stage. The venue will be the 'KKL Luzern', the Culture and Convention Centre Lucerne (http://www.kkl-luzern.ch). This magnificent building was designed by French architect Jean Nouvel. Built between 1995 and 2000, the KKL ranks today as one of the most spectacular modern buildings in Switzerland. It is centrally located in the town of Lucerne, directly on Lake Lucerne and right next to the railway station. The old town centre is only a few hundred metres from the KKL Luzern, as is Lucerne's distinctive landmark, the Chapel Bridge.

IFP-Sponsored Master Classes, Workshops and Seminars: The aim of these events is threefold, namely to help disseminate novel, evidence-based psychotherapeutic approaches, to raise the international profile and recognition of the IFP and to recruit individual IFP members, thus generating income for the IFP. A workshop on Brief Eclectic Psychotherapy for PTSD with Prof. Berthold Gersons (Amsterdam) is planned for April 2008 in Vienna, one on cognitive-behavioural therapy for eating disorders with Prof. Chris Fairburn (Oxford) in summer 2008 in Zurich, and a seminar on psycho-oncology will be organized by Board member Prof. Mechthild Neises in Hannover, Germany, in fall 2008.

\section{KARGER}

Fax +4161306 1234

E-Mail karger@karger.ch

www.karger.com
(C) 2008 S. Karger AG, Basel

0033-3190/08/0771-0067\$24.50/0

Accessible online at: www.karger.com/pps 
Collaboration with Other International Societies: I was invited to serve on the International Advisory Committee for the 5th WCP World Congress of Psychotherapy, which is organized by the World Council for Psychotherapy in Beijing, October 12-15, 2008. I was also invited to deliver a keynote address at this conference, which will provide me with an opportunity to further liaise with our Chinese partners and to strengthen our collaboration. Furthermore, IFP Council member Prof. David Orlinski, Chicago, invited me and WCP President Prof. Alfred Pritz to jointly organize a symposium on the profession of psychotherapist at the 39th international meeting of the Society for Psychotherapy Research (SPR), which will be held in Barcelona, Spain, June 18-21, 2008.

Finally, as always, all our members, meaning individual members of the IFP as well as individual members of associations who have membership status with the IFP, are offered the IFP's official journal, Psychotherapy and Psychosomatics, at a substantially reduced subscription rate. For details, please contact S. Karger directly at:

$$
\begin{aligned}
& \text { S. Karger AG } \\
& \text { Journals distribution } \\
& \text { PO Box } \\
& \text { CH-4009 Basel (Switzerland) } \\
& \text { Fax +41 } 613061234 \\
& \text { E-Mail karger@karger.com }
\end{aligned}
$$

Best regards

Prof. Ulrich Schnyder, MD

President, IFP

u.schnyder@ifp.name

\section{Psychotherapy Asia Pacific V: 'Listening to the Heart of the East'}

5th Congress of the Asia Pacific Association of

Psychotherapists, Jakarta, Indonesia, April 5-7, 2008

The psychotherapists of Indonesia have been honoured with the task of hosting Psychotherapy Asia Pacific V, and we extend a warm welcome to Jakarta in April 2008 to our colleagues in the region and beyond, and all who are professionally interested in this - and allied - fields. We hope to be able to set the stage to further consolidate our organization's shape and meaning and its link to mental health and well-being enterprises.

The scientific programme will be designed to cover a wide area of contemporary concerns about appropriateness of theories, applicability and effectiveness of techniques, emerging deviant patterns of individual and social behaviour, as well as psychopathology related to age group or social/ethnic group, to name just a few among the topics.

As a conference theme, we have invented 'Listening to the heart of the East' because we constitute a regional chapter, to direct a focus on local conditions and development. It is meant to inspire and stimulate thoughts on understanding - and better understanding through listening and relating, to undergird appropriate communication and action. Such a listening can probably not be generalized and must take local characteristics into account: traditional, ethnic, cultural, social, economic and political. The theme is not meant so much as a call to the world at large but mostly to the psychotherapists of 'the East' themselves, to listen to the heart and mind of their patients where they are. The experiences thus gained can hardly fail to be an important contribution to the art and science of psychotherapy - and we have a unique cultural programme too in store for you. Whatever we can do to make your visit to Jakarta worthwhile, see you there!

\section{Bachtiar Lubis}

Chairman, Organizing Committee, PAP V

\section{IFP Board}

www.ifp.name

Prof. Ulrich Schnyder, MD

President IFP

Zurich/Switzerland

u.schnyder@ifp.name

Alfried Längle, MD, PhD

Vice-President IFP

Vienna/Austria

a.laengle@ifp.name

Mechthild Neises, MD

Secretary General IFP

Hannover/Germany

m.neises@ifp.name

Michael Rufer, MD

Treasurer IFP

Zurich/Switzerland

m.rufer@ifp.name

\section{Secretariat IFP}

Cornelia Erpenbeck University Hospital Zurich Department of Psychiatry Culmannstrasse 8 CH-8091 Zurich/Switzerland

Tel. +41 442555251

Fax +41 442554408

secretariat@ifp.name 